\title{
CONCRETIZATION OF THE VALUES OF ISLAMIC CRIMINAL LAW IN THE RECONCEPTION OF CERTAIN PROVISIONS AS REASONS FOR CRIMINAL WEIGHT ON CORRUPTION IN INDONESIA
}

\author{
Rahman Fathor ${ }^{\star}$, Doctoral Candidate \\ Luth Thohir, Madjid Abdul, Noerdajasakti Setiawan, Lecturers \\ Faculty of Law, University of Brawijaya, Malang, Indonesia \\ *E-mail: rohmanfathor214@gmail.com
}

\begin{abstract}
Certain circumstances as the reason for the aggravation of corruption should not only be limited to the reasons as contained in Article 2 paragraph 2 of Law Number 20 of 2001 concerning Amendments to Law Number 31 of 1999 concerning the Eradication of Criminal Acts of Corruption, but there is an essential reason by adopting the values of Islamic criminal law. These values are divided into two major groups, namely: First are universal values whose philosophical basis is "maqosyid al-syar'iyah", by relying on the protection of five points in Islamic criminal law (kulliyah al-homsah) which includes religion (al-din), soul (alnafs), reason (al-aql), offspring (al-nasab), and property (al-mal), which in the context of a criminal act of corruption is "hifzdu al-mal" namely the protection of State assets, which in this case, if it is associated with the weighting of the crime of corruption, means that the weighting of the crime is based on how much the state has lost as a result of corruption. The second is fundamental values whose philosophical basis is "rohmatal lil alamin, which contains the value of al-adaalah, namely the values of justice that can be concretized against the weighting of corruption based on the quality of legal subjects; for example the perpetrator is a high-ranking state official; the value of al-tawkidiyah, which is the value of certainty, based on the existence of "nishab," which can be concretized against the weighting of corruption crimes based on the minimum limit of state financial losses, for example, the weighting of corruption can be imposed if the state financial losses are not less than one hundred billion rupiah; and the last is the value of al-maslahah, which is based on taking benefits and rejecting mafsadat or damage, which in the context of aggravating corruption means that it is based on the consequences of corruption in the form of systemic damage.
\end{abstract}

\section{KEY WORDS}

Basis of criminal weighting, corruption, certain circumstances, values of Islamic criminal law.

Current facts show that the development of law in Indonesia is quite significant, in line with the dynamic social development of society. Various kinds of problems faced by the State of Indonesia require the law to continue to move forward as a social controller and be at the forefront of creating an orderly, advanced and prosperous society. This legal development was marked by the birth of various new and special legal products, such as the issuance of Law Number 31 of 1999 as amended to Law Number 20 of 2001 concerning the Eradication of Criminal Acts of Corruption. In terms of legal institutions, namely the birth of an independent Law Enforcement Institution such as the Corruption Eradication Commission (KPK), which has special authority to eradicate corruption, although in reality it still needs to be improved, both in norms and in its implementation.

The enactment of Law Number 31 of 1999 as amended to Law Number 20 of 2001 concerning the Eradication of Criminal Acts of corruption is one of the demands and efforts to build a law to overcome the problems of the Indonesian state, which is facing a big problem of corruption (Danil, 2011), where statistically there have been many corruption cases that the Corruption Eradication Commission (KPK) has been legally processed. Many of the perpetrators have been convicted and have languished as convicts in correctional institutions (Soemartono, 2018). However, until now, corruption in Indonesia continues to increase from year to year, as if the existing legal instruments do not cause a deterrent effect and fear for 
someone to commit a criminal act of corruption. So that institutions such as the Corruption Eradication Commission (KPK), which was formed to eradicate corruption in Indonesia, continue to be busy with taking action but are unable to reduce the corruption index to the lowest level. In this reality, some groups want a reconception and reformulation of the Corruption Eradication Law (UUPTPK) in Indonesia.

Responding to the desire of several groups to immediately revise and renew Law Number 20 of 2001 concerning Amendments to Law Number 31 of 1999 concerning the Eradication of Criminal Acts of Corruption, the Government through the Ministry of Law and Human Rights, formed a team to prepare a Draft Law on the Eradication of Corruption Crimes (RUU PTPK) and has begun to be socialized by The team has been in existence since 2007, and was then renewed through the government's proposal in a text dated August 15,2012 . However, again in the draft, there is no change in the eradication policy and the form of punishment, as the public wants to make changes to the policy on the reasons for criminal aggravations with orientation to the reasons more firm and measurable reason, under the philosophical basis of eradicating corruption, which is to create a deterrent effect. At the same time aiming to restore state finances as a means of sustainable development and welfare of the Indonesian people, consideration in consideration of Law Number 31 of 1999 concerning the Eradication of Criminal Acts of Corruption, that: "Criminal acts of corruption are very detrimental to state finances or the state economy and hinder national development". So, based on these considerations, the criteria for the weighting of criminal sanctions should be in line with the legislative ratio for forming the Corruption Eradication Act.

Corruption has become so institutionalized in Indonesia. It takes high seriousness to be able to eradicate it by finding the right ways and solutions. One of them is to improve the legal substance (regulatory instruments), which is the basis for efforts to eradicate it, accompanied by the reconception and reformulation of the elements of aggravating the criminal act of corruption, by exploring the values that live in society, because in reality, the law appears in the relationship process interaction between humans, namely in the form of awareness and the necessity to behave in specific ways and certain situations. Then the law will be effective if the law created is in harmony with the values that live in the community itself. This means that with the creation of law, people feel that justice will be achieved through the process of creating a harmonious and balanced relationship with the determination and appreciation of values that grow in situations and conditions where the community is involved in the process of interaction in it, both interactions with fellow humans and responsibility to God Almighty.

The problem of corruption is an issue that is closely related to moral issues so that through the moral values contained at the core of Islamic teachings, it is hoped that we will be able to find several formulations to answer the challenges of corruption problems in Indonesia through the spirit of Islamic law reform. And in this case, it is certainly not an exaggeration if the Renewal of the Law on the Eradication of Criminal Acts of Corruption in Indonesia, especially the one that covers the concept of weighting criminal sanctions for corruption in Indonesia, is based on the values of Islamic criminal law, because in addition to the majority of Indonesian people, adhere to Islam Juridically, Islamic law has the same position as a source of norms for efforts to establish and renew national law, in addition to customary law and western law.

As is widely understood, the Islamic criminal building (al-Jinayah wal Jarimah alIslamiyah) (Hanafi, 1967) as described in shari'ah and fiqh is general divided into three; namely Hudud, Qishash/Diyat, and Ta'zir. The first type (hudud) is the right of Allah so that its provisions are determined by Allah clearly and firmly in the Qur'an and al-Hadith. The next classification is the crime (jarimah) qishas and diyat, namely crimes that target the integrity of the human body intentionally or unintentionally. The last classification is Jarimah Takzir. That is Jarimah which is not regulated clearly and firmly in the Qur'an, but is handed over to the Ruler or Qodi. Thus, corruption is not regulated clearly and firmly in the Qur'an and Al-Hadith, because at that time, the term corruption was not known, but in the perspective of Islamic criminal law, doctrinally every form of al-ma'siyyah open to criminalization is determined as a 
crime (Asmawi, 2013). Doctrinally, corruption is included in the domain of ta'zîr criminalization, which is realized through the role of judges (in the form of court decisions) or the authority of the government or authorities (in the form of legislation), or by using the ijtihad method (Qias), where corruption can be equated with criminal acts that already have provisions in the Qur'an and Al-Hadith, such as crimes of al-syariqoh, al-hirobah, and so on.

Speaking of changes and reforms in criminal law, including the renewal of the law on the Eradication of Criminal Acts of Corruption, the policy on the reasons for the weighting of sanctions is very urgent in its position in the context of upholding the rule of law. In Indonesia, the reasons for the aggravation of corruption are contained in Article 2 paragraph 2 of Law Number 20 of 2001 concerning Amendments to Law Number 31 of 1999 concerning the Eradication of the Crime of Corruption, which is a weighting of the sanctions regulated in Article 2 paragraph (1), which reads as follows:

"Every person who unlawfully commits an act of enriching himself or another person who is a corporation that can harm the state's finances or the state's economy is sentenced to life imprisonment or a minimum of 4 (four) years and a maximum of 20 (twenty) years ) years and a fine of at least Rp. 200,000,000.00 (two hundred million rupiahs) and a maximum of Rp. 1,000,000,000.00 (one billion rupiah)".

While the weighting is regulated in Article 2 Paragraph (2), which reads as follows: "If the criminal act of corruption as referred to in paragraph (1) is committed under certain circumstances, the death penalty may be imposed". The reasons for the aggravation of criminal acts of corruption in "certain circumstances" as mentioned above are still conventional, unclear, incomplete, and multi-interpreted so that until now, no defendant in a corruption case has been sentenced to the death penalty. However, he was legally and convincingly proven to have harmed the state's finances which were so large and had damaged moral values and governance. On that basis, it is necessary to reconceptualize and reformulate the reasons for the weighting of corruption that are more measurable and become shocking therapy for perpetrators of corruption in Indonesia by adopting the values of Islamic criminal law, especially related to the criteria and reasons for the weighting of corruption, which has been included in the category of serious corruption (Ruba'i, 2017).

So far, the handling of corruption cases, especially when approached philosophically, raises fundamental problems, especially when associated with the legal ontology in terms of concepts and reasons for the aggravation of corruption. The reasons for the aggravation of corruption in Indonesia, as stated in Article 2 paragraph 2 of Law Number 20 of 2001 concerning Amendments to Law Number 31 of 1999 concerning the Eradication of Criminal Acts of Corruption, is based on "certain circumstances". What is meant by "certain circumstances" in this provision are elements of aggravating criminal sanctions for perpetrators of criminal acts of corruption, with the threat of punishment being the death penalty? However, this death penalty has never been imposed on perpetrators of criminal acts of corruption, because the criteria or conditions of "Specific Circumstances" as a reason for criminal aggravation for perpetrators of criminal acts of corruption are considered unclear and incomplete. After all, the norms are not explicitly formulated in the formulation of articles in the body of the law. Still, it is only formulated in the explanation of Article 2 paragraph 2 of the law, which reads as follows:

What is meant by "certain circumstances" in this provision is a situation that can be used as a reason for criminal aggravation for the perpetrators of criminal acts of corruption, namely if the crime is committed against funds that are designated for the management of dangerous conditions, national natural disasters, management due to social unrest widespread, overcoming the economic and monetary crisis, and the repetition of criminal acts of corruption".

Whereas if it is understood the explanation tends to narrow the meaning and purpose of "Certain Circumstances" because "Certain Circumstances" is intended as a criminal offense if a criminal act of corruption is committed against the object of a criminal act of corruption (only limited to the funds that have been mentioned in the explanation of the article), while other funds, which are no less important when compared to these funds, such as funds related to taxes, funds for education development, funds for poverty alleviation, and 
others, cannot be reached by using article 2 paragraph 2 of this, and this becomes a separate problem when it is associated with the theory and concept of legislation, especially regarding the position of explanation in a dandang law whose provisions are contained in the attachment of Law Number 15 of 2019 concerning Amendments to Law Number 12 of 2011 concerning the Establishment of Legislation, which stipulates that the explanation of the law may not contain norms and may not expand, narrow or add to the meaning of norms in the body of the act, as stated in Attachment II of the Law in Attachment II E-No points 186 concerning the Elucidation of the Law, on page 35, namely, the formulation of the explanation article by article takes into account the following: a. does not conflict with the main material regulated in the body; b. does not expand, narrow, or add to the meaning of the existing norms in the body; c. not to repeat the main material regulated in the body; $d$. does not repeat the description of words, terms, phrases, or meanings that have been contained in the general provisions; and/or e. does not contain the delegation formula.

So based on these provisions, actually the legal explanation functions as an official explanation of what is desired by the legislators on certain norms in the body, which only contains descriptions of words, phrases, sentences and may not expand, narrow, or add to the understanding of the norms that exist in the body, because the explanation is an attempt to clarify the norms in the body so that the explanation should not cause new ambiguity of the norms in question.

The ideals of changing the law towards a law that is fair and under reality are rooted in the values that exist in society, including, in this case, the renewal of the law on the Eradication of Corruption Crimes which is currently regulated in Law Number 20 of 2001 in conjunction with Law Number 31 of 1999 concerning the Eradication of Criminal Acts of Corruption, this is under the principles of legal development contained in the vision and direction of the National Long-Term Development Plan for 2005-2025, which are as follows:

"... one of the tasks that have not yet been completed is establishing an Indonesian National Law System that reflects the ideals, soul, spirit, and social values that live in Indonesia. Efforts have been made, among others (1) renewal of laws and regulations; (2) empowerment of existing legal institutions/institutions; (3) improving the integrity and morale of law enforcement officers and other legal apparatus; accompanied by (4) improvement of adequate legal facilities and infrastructure...".

Therefore, in the preparation of national law, it can be taken from any legal source, as long as the majority of the community can accept the created laws. Likewise, Islamic law can be used as a reference in the process of drafting and renewing Law Number 20 of 2001 concerning Amendments to Law Number 31 of 1999 concerning the Eradication of Criminal Acts of Corruption, because Islamic law fulfills the requirements, namely: Islamic law is under the needs of the community and is objectively acceptable (Hutagalung, 1985) as a source of law in a renewal of national law, including in this case the renewal of the law on the Eradication of Corruption Crimes. Based on the background stated, this article will discuss the concretization of the reconception of "certain circumstances" in article 2, paragraph 2 of the law on the Eradication of Non-Corruption Crimes based on the values of Islamic criminal law for the future in Indonesia.

\section{RESULTS AND DISCUSSION}

"Certain Circumstances" must be re-conceived as elements of aggravating corruption in Indonesia based on all the more rational possibilities, one of which is based on the values of Islamic criminal law, where the values of Islamic criminal law consist of two parts. The Universal Islamic Criminal Law Values are Fundamental in nature based on "Maqosyd Alsyar'iyah, and the Islamic Criminal Law values, which include Universal Fundamental values, whose philosophical basis is "Rahmatal lil-aalamin" which contains the elements: Al-adaalah, Al-taukidiyah and al-maslahah. From the values as mentioned above, it can be concretized into a reconception of the reasons for the aggravation of corruption in Indonesia, as will be reviewed as follows: 
The concretization of the reconception of the reasons for the criminalization of corruption based on universal values in islamic criminal law. The universal values of Islamic criminal law are basic values, which have the aim of protecting basic rights whose philosophical basis is maqosyid al-syar'iyah and generally applies and universally, which includes five basic values based on the maintenance of five the main thing (al-kuliyat alkhamsah), which includes religion (al-din), soul (al-nafs), reason (al-aql), offspring (al-nasab), and property (al-mal). This universal value is considered the main goal of shari'ah (maqasyid al-syari'ah) as stated by AL-Syatibi (Fina, 2011). In weighing the elements of corruption, the five points that are universally protected in Islamic criminal law are related to the protection of property (al-mal), which in this case is state finances. It is at this point that the criminal act of corruption is qias-kan with acts and acts of theft (al-sariqoh), serious theft (al-hirobah), abuse of authority (al-ghulul) and bribery (al-riswah). The crime of corruption can be equated with these things because it has the same illat (reason for enactment of the law) with these acts. Based on the description above, when the criminal act of corruption is characterized by theft, the elements of aggravating corruption should be based on the amount of state financial losses. The elements of aggravating the criminal offense of corruption which are already based on the state's financial losses, then based on the values of Islamic criminal law, must be manifested into values that include fundamental values consisting of Protective Values, which in terms of this is the concretization of these values in the form of laws (taqnin/qonun) whose function is to maintain the continuity of universal fundamental values which are summarized in the five main points of maqosyid al-syar'iyah. Because these protection values are taknin and are part of these universal fundamental values, concerning the context of corruption, the formulation of the weighting must be clear, so that there is no doubt, especially for judges in taking a verdict, which is closely related and interdependent also with the next value, namely implementational values. Implementation value is a specific action or measure carried out or used to implement protection values (Fina, 2011). For example, the weighting of the crime of corruption, which has been based on state financial losses, must be enforced in a legal process that is afraid of anyone who violates it. That the firmness of the formulation of the weighting of corruption due to the contextualization of the nishab in Jarimah Al-Sariqoh, is an immersion of the Instructional Values of Islamic criminal law, which is a measure or action contained in the Qur'an an issue that (applies) specifically in a case such as theft, which is a direct instruction from Allah Almighty, which is contained in the Qur'an which is Instructional.

The concretization of the reconception of criminal corruption based on fundamental values in islamic criminal law. In addition to universal values in Islamic criminal law, the formulation of the weighting of corruption can be based on fundamental criminal law values. These values contain very basic goodness and truth and can be universally accepted both by Muslims themselves and by others. non-Muslims, because it is based on the general welfare, and its philosophical basis is on the concept of rahmat li al-lamin, which is the actualization of fundamental values in established legal theory, namely: Values of Justice, Certainty, and Benefit. That Islam is a religion of justice, on the other hand, strongly fights injustice. Corruption is abuse that directly challenges the enforcement of justice. Al-'adalah is the keyword in Islam. This is why the purpose of tasyrî' law (maqasyid al-ahkam al-syar'îyah) is rahmat li al-'alamin (grace for the whole world). This grace is explained through tahzib al-fard (educating and improving individuals) for the sake of human dignity, iqâmat al-'adl fi aljamâ'ah (enforcing social justice), and tahqiq al-masalih (creating benefits) (Permono, 1994). The concept of rahmat li al-alamin is grand and majestic. This concept is one sign of how Islam is expected to be teaching needed by all mankind and the entire universe, not only for people who have become believers. Prophet Muhammad brought Islam in gifts of happiness. The language of happiness is broader and more universal than truth. Islam comes as hope and optimism to get out of pain and torment since humans live until after being revived. Associated with corruption, Islam and rahmat li al-alamin explain that corruption is an ignorant behavior that must be resolved. Islam teaches that oppression, arbitrariness, and abuse are attitudes of life that can hurt other human beings. Islam does not like irresponsible attitudes like this, so Islam focuses almost all of its teachings on eradicating these attitudes. 
The goal is that all human beings can live well, with dignity and happiness. Islam is a way out of oppression, injustice, and feelings of unhappiness.

The value of justice is the main and first value in the Fundamental values in Islamic Criminal law. Associated with corruption, these values of justice, the teachings of Islam against corruption are very strict: haram and forbidding. There are many reasons why corruption is strictly prohibited in Islam. Apart from being in principle against the social mission of Islam, which wants to uphold social justice and the benefit of the universe (iqamat al-'is alijtimaiyyah wa al-mashlahat al-ammah), corruption is also considered an act of betrayal of the mandate received and serious damage to the building system accountable. Therefore, both the Qur'an, Al-Hadith, and ijma' al-'ulama express their prohibition (sharih).

In the context of the reconceptualization of the elements of the weighting of corruption, the values of justice in Islamic criminal law can be used as a basis and reason because it is based on the concept of justice in the perspective of Islam itself, which means that the reason for the weighting of corruption must be based on who did what. In other words, this weighting is based on legal subjects, namely if the perpetrator of a criminal act of corruption is a high state official who has committed a criminal act of corruption with a very large number of state financial losses, based on the contextualization of nishab in the crime of alsyariqoh as the reconsideration of criminal weights based on the values of the universal Islamic criminal law above. In the weighting of the criminal element of corruption here, it is in line with Al-gulul, where at the time of the Prophet, the legal subjects were mujtahids who fought in the battlefield who then took the spoils of war outside their rights and if contextualized now are high state officials. In addition to al-gulul, in this context, corruption can be compared to al-riswah, namely in the form of bribery. In the Indonesian context, the weighting of corruption is based on legal subjects, who bribes and accepts bribes, and how much the nominal amount of the bribery is. It becomes clear that the weighting will be based on legal subjects. Those who commit bribery are high state officials, for example, officials as high as the Minister or officials as high as members of the People's Representative Council, and others.

In addition to the values of justice as mentioned above, the second fundamental values in Islamic criminal law are the values of Al-Tawqidu, which comes from the Arabic word, which means sure. In Islamic criminal law, there are values of legal certainty, which guarantees that a law must be carried out in a good or appropriate way based on the provisions of nash or syar'i rules. These values are based on the letter al-Qashsash verse 59. This verse says that "Allah will not punish anyone unless he has sent His Messenger". In this regard, the formulation of the elements of aggravating the crime of corruption must be clear and firm in a statutory regulation that as much as possible does not cause hesitation for judges to make a decision. In this case, it is relevant if the criminal act of corruption is aligned with all the Islamic criminal provisions representing the criminal act of corruption. Suppose the criminal act of corruption is sentenced to qiyas with al-syariqoh. In that case, the formulation of state financial losses must be precise on the minimum limit of the state money being corrupted. The perpetrators of corruption can be qualified to have met the elements of aggravating the crime of corruption.

The last one related to the transformation of fundamental values in Islamic criminal law into the reconception of the elements of aggravating the crime of corruption is the value of $\mathrm{Al}$ maslahah or benefit in law, namely how the values of criminal law can create benefit. The creation of benefit is to intervene and innovate a balanced situation during society to live in a supportive climate for good. The benefit is a fundamental and universal human principle about goodness and a good way of life for the broadest possible society. Among the benefits to be addressed is how the welfare of society can be formed. If it is associated with corruption, then corruption in Islam is an act of violating the Shari'a. Islamic law aims to realize the benefit of mankind with what is referred to as maqasyid al-syar'iyah, one of which is the maintenance of property (hifdz al-mal) from various forms of violations and abuses. Thus, if these maslahah values are transformed into a reconception of the elements of aggravating corruption in Indonesia, this is in harmony if corruption is contextualized with 
jarimah al-hirobah, which in verse explaining about hirobah focuses on the illat of damage, as Allah says, namely: in the Qur'an letter Al-Maidah verse: 33, which reads as follows:

"Indeed, the compensation of those who fight against Allah and His Messenger causes mischief in the earth. They are killed or crucified or have their hands and feet cut off on opposite sides, or are banished from the land (of their dwellings). That is an insult to them in this world, and in the Hereafter, they will have great torment." (Al-Maidah: 33).

So the reconception of the elements of aggravating corruption in Indonesia, based on the values of al-maslahah, means that the concept of weighting is based on the consequences caused by corruption, namely in the form of systemic damage both concerning the economic, political, and state security systems, such as examples of actions resulting from corruption. Corruption of the state's finances into a deficit, or the country falls into a monetary crisis.

Table 1 - Islamic Criminal Law Values

\begin{tabular}{|c|c|c|c|c|c|}
\hline No & $\begin{array}{l}\text { Islamic } \\
\text { Criminal Law } \\
\text { Values }\end{array}$ & $\begin{array}{l}\text { Philosophy } \\
\text { Base }\end{array}$ & Various Values & Form & $\begin{array}{l}\text { Concretion Reconception } \\
\text { Weighting Corruption } \\
\text { Criminal Sanctions for } \\
\text { the Future in Indonesia }\end{array}$ \\
\hline \multirow{3}{*}{1} & \multirow{3}{*}{$\begin{array}{l}\text { Fundamental } \\
\text { Values in } \\
\text { Islamic } \\
\text { Criminal Law }\end{array}$} & \multirow{3}{*}{$\begin{array}{l}\text { Maqosyid } \\
\text { Al- } \\
\text { Sayr'iyah }\end{array}$} & Protection values & $\begin{array}{l}\text { (al-hifdhiyah) legal } \\
\text { protection in the form of } \\
\text { orders or prohibitions in- } \\
\text { law/statutory regulations } \\
\text { (Taknin/Qonun) }\end{array}$ & $\begin{array}{l}\text { The formulation of the } \\
\text { reasons for the weighting } \\
\text { of Corruption Criminal } \\
\text { sanctions must be clear } \\
\text { and firm }\end{array}$ \\
\hline & & & $\begin{array}{l}\text { Implementational } \\
\text { Values }\end{array}$ & $\begin{array}{l}\text { (al-tathbiqiyah Al- } \\
\text { syar'iyah) Its application } \\
\text { is under the provisions } \\
\text { that have been in force } \\
\text { and has the value of } \\
\text { juridical, sociological, and } \\
\text { philosophical } \\
\text { applicability. }\end{array}$ & $\begin{array}{l}\text { The reason for the } \\
\text { aggravation of the crime } \\
\text { is based on provisions } \\
\text { that are easy to } \\
\text { understand and easy to } \\
\text { apply, taking into account } \\
\text { things that are concrete } \\
\text { and measurable }\end{array}$ \\
\hline & & & $\begin{array}{l}\text { Instructional } \\
\text { Values }\end{array}$ & $\begin{array}{l}\text { (al-amriyah) } \\
\text { commandments of Allah } \\
\text { and His Messenger and } \\
\text { the Ruler (Ulil Amri) }\end{array}$ & $\begin{array}{l}\text { The weighting of } \\
\text { corruption must be } \\
\text { carried out in accordance } \\
\text { with the orders of the } \\
\text { legislation }\end{array}$ \\
\hline \multirow{3}{*}{2} & \multirow{3}{*}{$\begin{array}{l}\text { Universal } \\
\text { Values in } \\
\text { Islamic } \\
\text { Criminal Law }\end{array}$} & \multirow{3}{*}{$\begin{array}{l}\text { Rahmatal } \\
\text { Lil- Alamin }\end{array}$} & $\begin{array}{l}\text { Al-adalah Fi Al- } \\
\text { syar'iyah (Justice) }\end{array}$ & $\begin{array}{l}\text { (al-mu'adalat fi al-qonuni) } \\
\text { equality before the law, } \\
\text { and not equality in } \\
\text { punishment, depending } \\
\text { on who does what }\end{array}$ & $\begin{array}{l}\text { The reason for the } \\
\text { weighting of corruption is } \\
\text { based on legal subjects, } \\
\text { such as high state } \\
\text { officials }\end{array}$ \\
\hline & & & $\begin{array}{l}\text { Al-Taukid fi Al- } \\
\text { syar'iyah } \\
\text { (certainty) }\end{array}$ & $\begin{array}{l}\text { Al-Nisab (minimum limit } \\
\text { of corrupted } \\
\text { goods/money: (qiyas } \\
\text { corruption with theft) }\end{array}$ & $\begin{array}{l}\text { The weighting of } \\
\text { corruption is based on } \\
\text { state financial losses, } \\
\text { and the minimum limit is } \\
\text { determined so that the } \\
\text { perpetrators can be } \\
\text { subject to heavier } \\
\text { sanctions for corruption. }\end{array}$ \\
\hline & & & $\begin{array}{l}\text { Al-Maslahah fi Al- } \\
\text { syar'iyah (benefit) }\end{array}$ & $\begin{array}{l}\text { (Dar'ul mafasid } \\
\text { muqoddamu ala jalbil } \\
\text { manafi') Reject mafsadat } \\
\text { and achieve benefits }\end{array}$ & $\begin{array}{l}\text { The reason for the } \\
\text { weighting of corruption is } \\
\text { based on the } \\
\text { consequences, to } \\
\text { prevent damage and } \\
\text { achieve benefits in the } \\
\text { form of welfare for the } \\
\text { community in general }\end{array}$ \\
\hline
\end{tabular}

In connection with the reasons for the aggravation of corruption, and line with the author's explanation above, the Supreme Court has issued Court Regulation (Perma) Number 1 of 2020 concerning Guidelines for the Criminalization of Article 2 and Article 3 of the Law on the Eradication of Criminal Acts of Corruption. Perma 1/2020 Criminal Guidelines 
contain regulations on how the stages must be carried out by judges in imposing criminal penalties (penalties or straftoemeting) against Article 2 and Article 3 cases of the Corruption Eradication Act. This indicates that, in fact, Article 2 paragraph 2 of the law on the Eradication of Criminal Acts of Corruption, is not sufficient to be used as a measure in determining the judge's decision, so with this fact, it is very reasonable that Article 2 paragraph 2 concerning the weighting of the crime of corruption must be re-conceived and reformed, so as not to become a redundant legal norm (in vain).

Perma Number 1 of 2020 concerning Guidelines for the Criminalization of Article 2 and Article 3 of the Law on the Eradication of Criminal Acts of Corruption was born to avoid criminal disparities for cases of the same character. This aims to provide certainty and proportionality in imposing a sentence. This provision emphasizes the judge to give reasons for the things that illustrate the severity of the punishment to be imposed. With the sentencing guidelines for judges as regulated in the Perma, it is hoped that in the future, in existing corruption cases, judges will not only consider a general nature, especially as stipulated in article 2 paragraph 2, which the author has analyzed above. In determining the severity of the crime, the judge must consider sequentially the stages of the existing sentencing guidelines, namely:

1. Category of state financial loss or state economy;

2. Error rate, impact, and profit;

3. The period for the imposition of a crime;

4. Aggravating and mitigating circumstances;

5. Criminal convictions: and

6. Other provisions relating to criminal imposition

If Article 2 of the Law on the Eradication of Corruption Crimes is proven, then the applicable article regarding the category of state losses or the state economy is Article 6 Paragraph (1) Perma 1/2020, which is divided into 4 (four) categories as follows: The most severe category: Value of State Financial Losses or State Economics from criminal acts of corruption more than Rp100,000,000,000.00 (one hundred billion rupiahs); Heavy category: Loss of State Finance or State Economy from corruption crime of more than Rp. 25,000,000,000.00 (twenty five billion rupiah) up to Rp. 100,000,000,000.00 (one hundred billion rupiahs); Medium Category: State Financial Losses or State Economic Losses from criminal acts of corruption of more than Rp. 1,000,000,000.00 (one billion rupiah) up to Rp. 25,000,000,000.00 (twenty-five billion rupiahs); Mild category: Loss of State Finance or State Economy from corruption crime of more than Rp. 200,000,000.00 (two hundred million rupiahs) up to Rp. 1,000,000,000.00 (one billion rupiah).

Associated with the meaning of "Certain Circumstances," which still causes problems both philosophically, theoretically, normatively, and conceptually, with the presence of this Perma, it is hoped that judges will pay more attention to considerations of the severity of the sentence to be imposed. However, because this provision is only in Perma, it does not have coercive power. This Perma is only a guide for judges and cannot reach, let alone force other law enforcers, on handled cases. So for the author of article 2, paragraph 2, reconception must still be carried out to have coercive power for all parties. It is not enough only with the Perma. Although Perma follows up on "Certain Circumstances" in Article 2 paragraph (2), according to the author, it is very linear with the author's thoughts. However, this article still cannot solve the problems only with Perma as the author mentioned above.

Therefore, the author is of the opinion that the elements of aggravating the crime of corruption contained in the explanation of article 2 paragraph 2 of Law Number 20 of 2001 concerning Amendments to Law Number 31 of 1999 concerning the Eradication of Criminal Acts of Corruption, interpreted as "conditions that can be used as a reason for criminal aggravation for perpetrators of criminal acts of corruption, namely if the crime is committed against funds intended for handling dangerous situations, national natural disasters, handling the consequences of social unrest that is widespread, overcoming economic and monetary crises, and repetition of criminal acts of corruption" is irrelevant to the development and demands of the community, so that the reasons for the aggravation of corruption are more measurable and rational, so in this case the author offers that the concept of "Certain 
Circumstances" be reconceptualized as Certain Things" and their elements are mentioned in the body of article 2 paragraph 2, not only contained in the explanation, with the concretization as follows; "In the case of a criminal act of corruption as referred to in paragraph 1, the death penalty can be remembered, if it fulfills certain things as follows: a criminal act of corruption causes state financial losses of not less than 100 billion rupiah; corruption is committed by high state officials; criminal acts of corruption cause systemic damage to the state administration, in the fields of economy, politics and security; The crime of corruption is carried out in the circumstances as referred to in the explanation of Article 2 paragraph 2 of Law Number 31 of 1999 quiet eradication of corruption; The perpetrators of criminal acts of corruption have repeated the crime of corruption based on court decisions that have permanent legal force.

\section{CONCLUSION}

From the results of the discussion and analysis above, it can be concluded as follows, the concretization of the reconception of the weighting of corruption based on the values of Islamic criminal law for the future in Indonesia needs to be done because the weighting of corruption crimes should not only be based on "Certain Circumstances" as contained in article 2 paragraph 2 of the law on the Eradication of Crimes. Corruption (UUPTPK), but there are reasons for the aggravation of corruption which is more essential by adopting the values of criminal law: First are the universal values of Islamic criminal law whose philosophical basis is "maqosyid al-syar'iyah", by relying on the protection of five points in Islamic criminal law (kulliyah al-homsah) which in the context of corruption is "hifzd al-mal" namely the protection of state assets, it means that the weighting is based on how much loss the state has. The second is the fundamental values whose philosophical basis is "rohmatal lil alamin, which contains the value of al-adaalah, which can be concretized against the weighting of corruption crimes based on the quality of legal subjects; The value of altawkidiyah, which is the value of certainty, based on the existence of "nishab," which can be concretized against the weighting of corruption crimes based on the minimum limit of state financial losses; And the last is the value of al-maslahah, which in the context of weighting the crime of corruption means that it is based on the consequences caused by criminal acts.

\section{RECOMMENDATIONS}

"Certain Circumstances" as the reason for the aggravation of corruption should be reconceived, because based on the results of this study, in addition to having found reasons for the aggravation of corruption which is not only based on the concept of "Certain Circumstances" but there are other, more fundamental reasons, namely: If the criminal act of corruption causes state financial losses of not less than 100 billion rupiahs; High state officials commit corruption crimes; The crime of corruption causes systemic damage to the state administration, in the fields of economy, politics, and security. And therefore, the concept of "Certain Circumstances" should be reconceptualized into "Certain Matters" so that legal norms do not conflict in essence with the actual legal concept. And it is normalized in the body of Article 2, paragraph 2 of the law on the Eradication of Criminal Acts of Corruption, not only contained in the explanation of articles and paragraphs as appears in the law on the Eradication of Criminal Acts of Corruption which is currently in effect in Indonesia.

Based on the recommendation of point an above, the author then provides editorial recommendations to be normalized in the body of article 2 paragraph 2 of the Corruption Eradication Act as follows:

"The death penalty can be imposed on the perpetrators of corruption as referred to in paragraph (1) if they have fulfilled "certain things" as follows:

- State financial loss due to corruption is not less than 100 billion rupiah; and/or

- High state officials commit corruption crimes; and/or 
- The crime of corruption causes systemic damage in the fields of politics, economy, and security, as well as creates unrest for the community in general; and/or

- Perpetrators of criminal acts of corruption have repeated criminal acts of corruption; and/or

- Criminal acts of corruption are committed when the country is in a state of danger under applicable laws, when a national natural disaster occurs, or when the country is in a state of economic and monetary crisis.

\section{REFERENCES}

1. Asmawi. (2013). Teori Al-Maslahah and Aplikasinya dalam Norma Kriminalisasi UndangUndang Anti korupsi. Jurnal Al-Ahkam. 13 (2).

2. Danil, E. (2011). Korupsi Konsep, Tindak Pidana and Pemberantasannya. Jakarta: Raja Grafindo Persada.

3. Fina, L. (2011). Interpretasi Kontekstual Abdullah Saeed: Sebuah Penyempurnaan Terhadap Gagasan Tafsir Fazlur Rahman. Jurnal Hermeneutik. 9 (1).

4. Hanafi, A. (1967). Asas-asas Hukum Pidana Islam. Jakarta: Bulan Bintang.

5. Hutagalung, M. (1985). Hukum Islam Dalam Era Pembangunan. Jakarta: Ind Hill.

6. Permono, S. (1994). Kontekstualisasi Fiqih dalam Era Globalisasi (Orasi IImiah dalam rangka Pengukuhan Guru Besar Madya dalam Ilmu Fiqih pada IAIN Sunan Ampel Surabaya). Surabaya: IAIN Sunan Ampel Surabaya.

7. Ruba'i, M. (2017). Bunga Rampai Kajian Hukum Yang Islami. Malang: UM Press.

8. Soemartono, S. (2018). Rekonstruksi Pembuktian Terbalik Pada Tindak Pidana Korupsi. Malang: Program Doktor IImu Hukum Universitas Brawijaya Malang. 